DOI 10.26724/2079-8334-2021-3-77-82-86

UDC 616.248-036.001.33

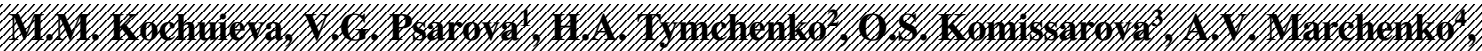

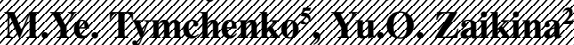

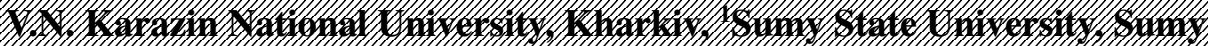

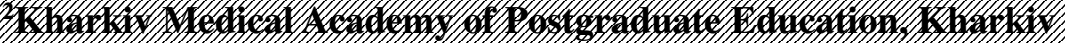

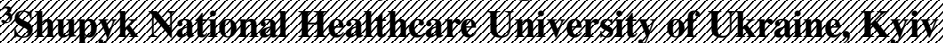

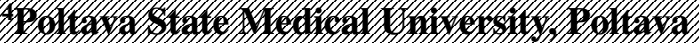

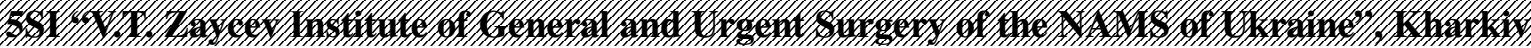

\title{
CLINICAL AND LABORATORY FEATURES OF PATIENTS WITH COMORBID ASSOCIATION OF BRONCHIAL ASTHMA AND OBESITY
}

e-mail: o.komis@ukr.net

The relevance of the study is due to the increased prevalence of the phenotype of bronchial asthma with obesity and its more severe course. The purpose of the study was to investigate the effect of excess body weight on the parameters of the clinical and laboratory condition of patients with bronchial asthma. 132 patients with bronchial asthma (76 women and 56 men), aged 35 60 years, 30 patients with normal weight and 102 patients with a body mass index of $25.0 \mathrm{~kg} / \mathrm{m} 2$ and more were examined. It was found that overweight patients with bronchial asthma have a longer duration of the disease (by $28.6 \%$ ) and corticosteroids (by $27.0 \%$ ), higher cardiovascular risk associated with increased diastolic blood pressure (by $5.3 \%$ ), decreased high-density lipoprotein (by $65.7 \%$ ), an increase in low-density lipoprotein (by 13.2\%) and glucose levels (by $5.1 \%$ ), an increase in interleukin-6 (by $31.8 \%$ ). Overweight correlations with age, spirometry, and symptom control were found in patients with asthma.

Key words: bronchial asthma, obesity, symptom control, disease course, cardiovascular risk

\section{М.М. Кочусва, В.Г. Псарьова, Г.А. Тимченко, О.С. Коміссарова, А.В. Марченко, М.Є. Тимченко, Ю.О. Заікіна КЛІНІКО-ЛАБОРАТОРНІ ОСОБЛИВОСТІ ХВОРИХ
3 КОМОРБІДНІСТЮ БРОНХІАЛЬНОЇ АСТМИ ТА ОЖИРІННЯ}

Актуальність роботи обумовлена збільшенням поширеності фенотипу бронхіальної астми з ожирінням та його більш важким перебігом. Мета роботи - дослідити вплив надлишкової маси тіла на параметри клініко-лабораторного стану хворих на бронхіальну астму. Обстежено 132 хворих на бронхіальну астму (76 жінок та 56 чоловіків), віком 35-60 років, 30 хворих з нормальною вагою та 102 хворих з індексом маси тіла від 25,0 кг/м2 і більше. Встановлено, що хворі на бронхіальну астму 3 надлишковою вагою мають більшу тривалість захворювання (на 28,6\%) та прийому кортикостероїдів (на 27,0\%), вищий серцево-судинний ризик, асоційований 3 підвищенням рівня діастолічного артеріального тиску (на 5,3\%), зниженням ліпопротеїдів високої щільності (на 65,7\%), підвищенням ліпопротеїдів низької щільності (на 13,2 \%) та рівня глюкози (на 5,1 \%), збільшенням інтерлейкіну-6 (на 31,8 \%). Виявлені кореляції надмірної ваги у хворих на бронхіальну астму з віком, показниками спірометрії та рівнем контролю симптомів.

Ключові слова: бронхіальна астма, ожиріння, контроль симптомів, перебіг хвороби, серцево-судинний ризик

The work is a fragment of the research project "Cellular, molecular and neurohumoral mechanisms of target organs remodeling, their relationships and correction in patients with combined pathology", state registration No. 0117 U006894.

Bronchial asthma (BA) is a chronic inflammatory disease of the respiratory tract, characterized by many phenotypes [4]. Large population studies show an increase in the prevalence of BA among obese patients regardless of their age $[6,10]$. Obesity has become a global epidemic, the prevalence of which has tripled in the last two decades [2]. Currently, the combination of BA and obesity is considered as a phenotype with its own clinical, biological and functional features.

The group of patients with BA on the background of obesity is not homogeneous. To date, two main phenotypes of the combination of asthma and obesity have been identified [1]:

with an early onset of the disease, this is a variant of allergic asthma with an increase in type $2 \mathrm{~T}$-helpers which is complicated by inflammatory processes in excess adipose tissue, and has a severe course of BA;

with a late onset, this is a variant of non-atopic asthma, most often found in women, accompanied by less pronounced inflammation of the respiratory tract than the first variant, but characterized by significant General metabolic changes and manifestations of oxidative stress of the respiratory tract, the development of this type is also affected by chronic compression of the lungs caused by obesity of the chest walls $[9,12]$.

According to the latest report of the Global Initiative for Asthma (GINA) in 2021, the obesity asthma phenotype is associated with a severe course and difficulties in achieving control of symptoms with standard baseline therapy [4]. The comorbid course of asthma and obesity is accompanied by a greater 
number of symptoms, worse indicators of external respiratory function (RF) and quality of life, insufficient response to the control therapy of asthma compared with the isolated form of asthma [10, 11], which in turn leads to an increase in the number of exacerbations of asthma and seeking medical help $[9,12]$.

Therefore, there is an urgent need for new treatment strategies for these patients. Weight loss is undoubtedly the leading approach, as numerous studies have shown that significant weight loss improves the symptoms of BA, RF, reduces the number of exacerbations and the risk of comorbidities such as cardiovascular disease and diabetes [11]. Bariatric treatment techniques are the most effective method of achieving weight loss [3], but bariatric surgery may be contraindicated in many overweight and obese patients with BA, therefore, non-surgical approaches are crucial for the treatment of asthma populations with obesity.

Despite the large number of studies on the combination of asthma and obesity, the mechanisms of pathogenesis, clinical and laboratory features, the impact on quality of life and the response to control therapy of comorbid course of these pathologies still remain unclear, and no specific recommendations have been developed for the comprehensive treatment of asthma with obesity, taking into account the needs of diet therapy and physical rehabilitation of this group of patients.

The purpose of the study was to investigate the effect of excess body weight on the parameters of the clinical and laboratory condition of patients with bronchial asthma.

Materials and methods. The study performed during 2018-2020 on the basis of the Department of Pulmonology of the Municipal Non-Commercial Enterprise "City Clinical Hospital No. 13" of the Kharkiv City Council (Kharkiv, Ukraine). The study included 132 patients with persistent BA of moderate severity. The diagnosis was established according to GINA recommendations [4].

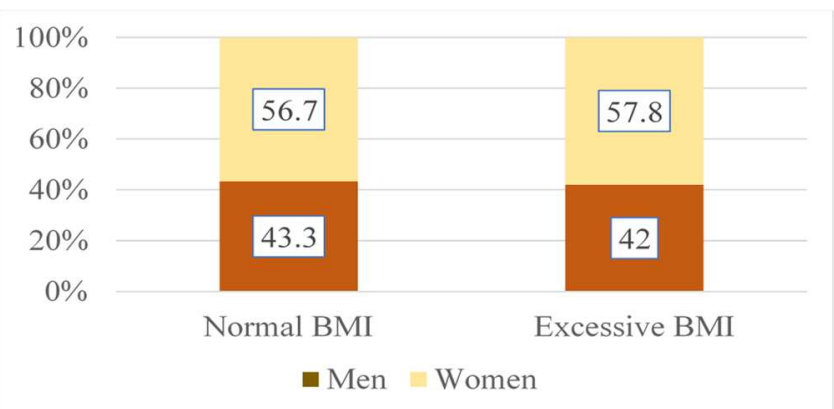

Fig. 1. Distribution in study groups by gender

According to the Body Mass Index (BMI = body weight, $\mathrm{kg} / \mathrm{height}, \mathrm{m} 2$ ), all patients were divided into two groups. The first group consisted of patients with a BMI of 18.5 to 24.9 $\mathrm{kg} / \mathrm{m}^{2}$, which is normal weight, and the second group consisted of overweight patients (BMI from $25.0 \mathrm{~kg} / \mathrm{m} 2$ to $29.9 \mathrm{~kg} / \mathrm{m}^{2}$ ) and obese patients (BMI from $30.0 \mathrm{~kg} / \mathrm{m}^{2}$ and more).

Among the patients, there were 76 women and 56 men, the groups were similar in gender composition ( $\mathrm{p}>0.05$ ) (fig. 1).

The study involved patients aged 35-60 years, the mean age was 52.64 \pm 8.24 years, in the group with a normal BMI $-53.20 \pm 9.16$ years, in the overweight group $-52.52 \pm 7.99$ years ( $p>0.05$ ) (fig. 2 ).

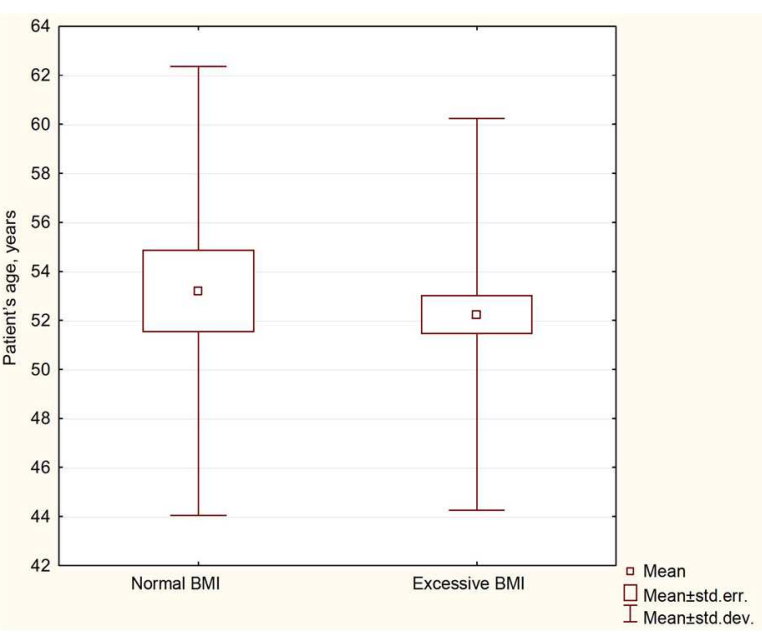

Fig. 2. Age composition of the studied groups

Exclusion criteria were: diabetes mellitus, chronic infectious, systemic, oncological and psychiatric diseases and chronic heart failure with left ventricular ejection fraction less than $55 \%$, history of myocardial infarction, stroke and signs of coronary heart disease.

The study was conducted in accordance with the Declaration of Helsinki adopted by the General Assembly of the World Medical Association, the European Union Convention on Human Rights and Biomedicine, Good Clinical Practice (GCP), relevant provisions of the World Health Organization (WHO) and Ukrainian law. All patients signed informed consent to participate in the clinical trial.

All patients underwent an examination, which included: general clinical examination - history taking and objective examination with anthropometric assessment of body weight, height, and calculation of body mass index (BMI), measurement of blood pressure (BP); a questionnaire using the Asthma Control Questionnaire-5 (ACQ-5) to determine the level of BA control; spirography using a computer system "SPIROCOM" (produced by the Research Institute "HAI-Medica", Kharkiv); laboratory tests - clinical blood test with a detailed leukocyte formula, determination of blood glucose levels, analysis of lipid profile indicators (low-density lipoproteins (LDL), high-density lipoproteins 
(HDL), total cholesterol), analysis of the content of immunoglobulin E (IgE), the content of interleukin4 (IL-4), interleukin-6 (IL-6), interleukin-8 (IL-8) was determined by the method of solid-phase enzymelinked immunosorbent assay.

All patients received standard baseline therapy with inhaled corticosteroids (ICS) and $\beta 2$-agonists of prolonged action according to the severity of the disease according to the recommendations of GINA [2]. The groups were comparable in age and asthma severity.

The obtained data were processed using the Statistica software. Quantitative data are presented as mean values (M) and standard deviations (SD). The critical value of the level of statistical significance in testing the null hypotheses was assumed to be equal to 0.05 . To compare the central parameters of the groups, we used parametric and nonparametric methods: Student's t-test, Wilcoxon and Mann-Whitney tests. The MannWhitney U-test was used to pairwise compare the groups, and the Spearman correlation coefficient was used to determine the relationship between the traits.

Results of the study and their discussion. Obesity in patients with BA is recognized as an important concomitant pathology that forms a unique phenotype and endotype. This comorbid condition reflects the close relationship between metabolic and inflammatory dysregulation. This study is devoted to the study of clinical and laboratory features of the course of BA on the background of different trophological status of patients.

According to the criterion of division into groups - BMI, the first group included patients with BA with normal weight $(22.33 \pm 0.37)$, and the second - with overweight $(30.76 \pm 4.34)(p<0.05)$. Patients with BA with overweight compared to the group with normal body weight had a significantly longer duration of the disease and the use of ICS by $28.6 \%$ and $27.0 \%$, respectively ( $\mathrm{p}<0.05)$ (Table 1), which in turn may indicate an earlier onset of BA and the need for ICS in this group of patients.

Table 1

Clinical and laboratory characteristics of the examined groups of patients $(\mathrm{m} \pm \mathrm{SD})$

\begin{tabular}{|l|c|c|c|c|}
\hline \multirow{2}{*}{ Index } & All patients with BA & $\begin{array}{c}\text { BA patients with } \\
\text { normal BMI }\end{array}$ & $\begin{array}{c}\text { BA patients with } \\
\text { excessive BMI }\end{array}$ & $\mathrm{p}$ \\
\cline { 2 - 5 } & $\mathrm{n}=132$ & $\mathrm{n}=30$ & $\mathrm{n}=102$ & $\mathrm{p}$ \\
\hline BA duration, years & $16.28 \pm 9.87$ & $12.43 \pm 8.61$ & $17.41 \pm 9.97$ & $\mathbf{0 . 0 1 1 4}$ \\
\hline ICS duration, years & $9.30 \pm 6.74$ & $7.23 \pm 6.13$ & $9.90 \pm 6.82$ & $\mathbf{0 . 0 4 9 3}$ \\
\hline ACQ-5, points & $1.21 \pm 0.25$ & $1.20 \pm 0.25$ & $1.22 \pm 0.25$ & 0.7446 \\
\hline FEV,$\%$ prop. & $67.11 \pm 5.96$ & $68.20 \pm 6.08$ & $66.79 \pm 5.92$ & 0.2599 \\
\hline Systolic BP, mm Hg & $133.71 \pm 14.71$ & $129.33 \pm 18.18$ & $135.00 \pm 13.35$ & 0.0867 \\
\hline Diastolic BP, mm Hg & $86.44 \pm 10.22$ & $82.83 \pm 11.35$ & $87.50 \pm 9.67$ & $\mathbf{0 . 0 3 2 8}$ \\
\hline IL-4, pg/ml & $133.71 \pm 14.71$ & $59.47 \pm 3.78$ & $66.20 \pm 22.30$ & 0.1645 \\
\hline IL-6, pg/ml & $99.24 \pm 44.65$ & $73.00 \pm 7.03$ & $106.96 \pm 43.53$ & $\mathbf{0 . 0 0 0 3}$ \\
\hline IL-8, pg/ml & $6.01 \pm 3.81$ & $5.34 \pm 0.36$ & $6.21 \pm 4.18$ & 0.8855 \\
\hline Glucose, mmol/L & $5.07 \pm 1.29$ & $4.87 \pm 1.82$ & $5.13 \pm 1.09$ & $\mathbf{0 . 0 3 6 6}$ \\
\hline LDL, $\mathrm{mmol} / \mathrm{L}$ & $3.16 \pm 0.70$ & $2.83 \pm 0.40$ & $3.26 \pm 0.74$ & $\mathbf{0 . 0 0 5 8}$ \\
\hline HDL, $\mathrm{mmol} / \mathrm{L}$ & $1.21 \pm 0.83$ & $1.74 \pm 0.86$ & $1.05 \pm 0.76$ & $\mathbf{0 . 0 0 0 7}$ \\
\hline Total cholesterol, mol/L & $5.91 \pm 1.41$ & $5.78 \pm 1.81$ & $5.95 \pm 1.28$ & 0.0939 \\
\hline IgE, IU/mL & $804.97 \pm 1103.35$ & $522.68 \pm 922.89$ & $885.24 \pm 1140.80$ & 0.2569 \\
\hline eosinophils, \% & $3.37 \pm 3.87$ & $3.20 \pm 3.18$ & $3.42 \pm 4.06$ & 0.7363 \\
\hline
\end{tabular}

There was a significant difference in the level of diastolic blood pressure: BA patients with overweight had a $5.3 \%$ higher diastolic blood pressure compared with patients with asthma with normal body weight $(\mathrm{p}<0.05)$. In the comparative assessment of groups of BA patients with normal weight and overweight, significant differences in other clinical and anamnestic parameters, RF and level of control were not detected $(\mathrm{p}>0.05)$.

Comparative analysis of systemic inflammation in the studied groups of patients showed a higher level of IL- 6 by $31.8 \%$ in the overweight group of BA patients compared with the group with normal BMI $(\mathrm{p}<0.05)$, although the levels of IL-4 and IL-8 did not have significant differences in these groups.

In the group of overweight patients with BA compared to the group with normal weight, glucose levels were significantly higher (by $5.1 \%$ ), although the average glucose levels in both groups were within normal limits (5.13 \pm 1.09 and $4.87 \pm 1.82$, respectively).

Evaluation of lipid metabolism revealed a 13.2 \% higher LDL level and a $65.7 \%$ lower HDL level in overweight patients with BA compared to normal-weight patients with BA $(p<0.05)$, which may indicate an increased cardiovascular risk in this group of patients. 
Indicators associated with the allergic profile of BA (IgE and eosinophils) did not have significant differences in the groups of normal weight and overweight patients with asthma.

To establish the relationship and determine the pathogenetic role of excess body weight (increased BMI) and the studied indicators, a correlation analysis was performed to determine the Spearman correlation coefficient (table 2).

Table 2

Correlations of BMI in the group of BA patients with elevated BMI

\begin{tabular}{|l|c|c|}
\hline \multicolumn{1}{|c|}{ Indices } & $\mathrm{r}$ & $\mathrm{p}$-value \\
\hline Patient's age, years & $\mathbf{0 . 2 9 9}$ & $\mathbf{0 . 0 0 2}$ \\
\hline Disease duration, years & 0.098 & 0.328 \\
\hline FEV1 before treatment, \% & $\mathbf{- 0 . 2 0 6}$ & $\mathbf{0 . 0 3 8}$ \\
\hline ACQ-5, points & $\mathbf{0 . 2 7 4}$ & $\mathbf{0 . 0 0 5}$ \\
\hline Systolic BP, $\mathrm{mm} \mathrm{Hg}$ & $\mathbf{0 . 2 1 1}$ & $\mathbf{0 . 0 3 3}$ \\
\hline Diastolic BP, mm Hg & $\mathbf{0 . 2 1 2}$ & $\mathbf{0 . 0 3 3}$ \\
\hline IL-4, pg/ml & -0.078 & 0.438 \\
\hline IL-6, pg/ml & -0.177 & 0.075 \\
\hline IL-8 pg/ml & 0.082 & 0.415 \\
\hline Glucose, mmol/L & $\mathbf{- 0 . 2 3 2}$ & $\mathbf{0 . 0 1 9}$ \\
\hline LDL, mmol/L & $\mathbf{0 . 4 2 5}$ & $\mathbf{0 . 0 0 0 0 0 8}$ \\
\hline HDL, mmol/L & -0.179 & 0.072 \\
\hline Total cholesterol, mmol/L & 0.109 & 0.281 \\
\hline IgE, IU/mL & $\mathbf{0 . 2 1 2}$ & $\mathbf{0 . 0 3 2}$ \\
\hline Eosinophils, $\%$ & -0.188 & 0.058 \\
\hline
\end{tabular}

According to the results of the assessment of the correlation of BMI and clinical and anamnestic data of overweight patients with BA, a positive relationship was found with the age of patients $\left(\right.$ age $_{\mathrm{r}}=0.299$, $\mathrm{p}=0.002$ ), the number of points on the ACQ- 5 questionnaire, which indicates the level of BA control (ACQ$\left.5_{\mathrm{r}}=0.274, \mathrm{p}=0.005\right)$, as well as a negative correlation with the RF $-\mathrm{FEV} 1$ index $\left(F E V 1_{r}=-0.206, p=0.038\right)$ $(\mathrm{p}<0.05)$.

A probable positive correlation was noted between BMI and the blood pressure - systolic $\left(\mathrm{SBP}_{\mathrm{r}}=0.211, \mathrm{p}=0.033\right)$ and diastolic $\left(\mathrm{DBP}_{\mathrm{r}}=0.212, \mathrm{p}=0.033\right)$.

According to the results of the assessment of the links between BMI and systemic inflammation indices (IL-4, IL-6, IL-8), no associations in the group of BA patients with overweight were found. Instead, there is a probable association between BMI and indices of the BA - positive allergic profile with $\operatorname{IgE}$ levels $\left(\operatorname{IgE}_{\mathrm{r}}=0.212, \mathrm{p}=0.032\right)$ and the tendency of negative association with blood eosinophil levels (eosinophils $\mathrm{s}_{\mathrm{r}}=-0.188, \mathrm{p}=0.058$ ).

An increase in body weight (in terms of BMI) has a likely correlation with metabolic changes in BA patients with overweight: a negative association with blood glucose levels and a positive association with LDL levels are likely $(\mathrm{p}<0.05)$.

Thus, our data demonstrate the negative effect of excess body weight on the course of BA.

In our study, increased BMI in asthma patients was likely to be associated with increasing patient's age, longer BA duration, and duration of ICS use, which may indicate a worsening of metabolic disorders with age and course of the disease. Instead, in a study by T. Villeneuve et al. it is indicated that the increase in the number of BA cases among obese patients does not depend on the age of the patient [10]. Current studies identify two main phenotypes by age of BA onset in combination with obesity - early-onset BA and late-onset BA [5], which differ significantly in gender composition, course, and pathogenetic mechanisms (primary obesity or BA) [7]. Therefore, depending on the predominance of one or another phenotype in the studied population, the association of age with the risk of developing BA with obesity will change. However, there is no doubt that the age of onset of BA comorbid with obesity is important to determine the leading phenotype of the disease, which in turn is important for predicting the course and effectiveness of basic treatment.

Comparative analysis of groups of normal and overweight BA patients did not reveal significant differences in the levels of RF violation and control of symptoms by ACQ-5. However, the correlation analysis allowed us to investigate the probable negative impact of increased BMI in patients with asthma on RF and disease control, which indicates a more severe course of the disease on the background of overweight. These results are confirmed in studies by U. Peters et al. [9], A. Mohan et al. [8], O.A. Carpaij [2] and others [10, 11]. 
The comorbid course of BA and obesity may contribute to the development of other comorbidities, such as cardiovascular disease, as evidenced by recent studies on this problem $[2,11]$. Our study revealed an increase in the mean level of diastolic blood pressure in the group of patients with BA and overweight, as well as a probable positive correlation between BMI and levels of systolic and diastolic blood pressure, which may indicate an increased risk of hypertension and diastolic dysfunction in this group of patients. Another group of factors that contribute to the development of cardiovascular disease are disorders of carbohydrate and lipid metabolism, which are observed in patients with BA with overweight and are likely to be associated with increased BMI.

The comparative study did not reveal a probable difference in the indicators of the allergic profile of BA depending on BMI, although a probable correlation was found between the level of IgE and BMI in the group of patients with asthma with elevated BMI. This result can be explained by a diverse group of patients by phenotypes, because the increase in $\operatorname{IgE}$ and eosinophils in the blood is more characteristic of the BA phenotype with obesity with early onset of the disease $[9,12]$.

All of the above indicates a significantly worse course of asthma in obesity, so understanding the relationship between these conditions can help in finding new therapeutic strategies for the treatment of this group of patients, which should include both pharmacological approach and specific treatment of obesity - a combination of diet and exercise.

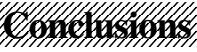

1. Patients with asthma with overweight differ from patients with BA with normal body weight probably longer duration of asthma and the use of ICS by $28.6 \%$ and $27.0 \%$, respectively, as well as higher by $5.3 \%$ level of diastolic blood pressure $(\mathrm{p}<0.05)$.

2 . The presence of excess body weight in patients with BA compared with normal weight patients is associated with major metabolic disorders - a probable decrease in HDL (by $65.7 \%$ ), increase in LDL (by $13.2 \%$ ) and glucose levels (by $5.1 \%$ ), as well as an increase in systemic inflammation - IL-6 (by $31.8 \%)(\mathrm{p}<0.05)$, which in turn indicates the presence of a higher cardiovascular risk in this group of patients.

3. Overweight patients with BA have likely correlations of BMI with age, RF, symptom control (ACQ-5 score), systolic and diastolic blood pressure levels, and metabolic status (glucose and LDL levels).

1. Bates JH, Poynter ME, Frodella CM, Peters U, Dixon AE, Suratt BT. Pathophysiology to phenotype in the asthma of obesity. Annals of the American Thoracic Society. 2017;14(Supplement_5). doi: 10.1513/annalsats.201702-122aw

2. Carpaij OA, van den Berge M. The asthma-obesity relationship. Current Opinion in Pulmonary Medicine. 2018; 24(1):42-9. doi: $10.1097 / \mathrm{mcp} .0000000000000446$

3. Evans S, Kurukulaaratchy RJ. The effect of bariatric surgery in the Difficult ASTHMA-OBESITY Phenotype: A case report. Journal of Asthma. 82012; 50(1):52-5. doi: 10.3109/02770903.2012.741639

4. Global initiative for asthma - global initiative for asthma [Internet]. GINA. 2021 [cited 2021Aug11]. Available from: https://ginasthma.org/

5. Lang JE, Bunnell HT, Lima JJ, Hossain MJ, Wysocki T, Bacharier L, et al. Effects of age, sex, race/ethnicity, and allergy status in obesity - related pediatric asthma. Pediatric Pulmonology. 2019;54(11):1684-93. doi: 10.1002/ppul.24470

6. Michalovich D, Rodriguez-Perez N, Smolinska S, Pirozynski M, Mayhew D, Uddin S, et al. Obesity and disease severity magnify disturbed microbiome-immune interactions in asthma patients. Nature Communications. 2019;10(1). doi: 10.1038/s41467-019-13751-9

7. Miethe S, Karsonova A, Karaulov A, Renz H. Obesity and asthma. Journal of Allergy and Clinical Immunology. 2020;146(4):685-93. doi: 10.1016/j.jaci.2020.08.011

8. Mohan A, Grace J, Wang BR, Lugogo N. The effects of obesity in asthma. Current Allergy and Asthma Reports. 2019; 19(10). doi: $10.1007 / \mathrm{s} 11882-019-0877-\mathrm{z}$

9. Peters U, Dixon A, Forno E. Obesity and Asthma. J Allergy Clin Immunol. 2018; 141(4):1169-79. doi: 10.1016/j.jaci.2018.02.004

10. Villeneuve T, Guilleminault L. Asthme et obésité de l'adulte. Revue des Maladies Respiratoires. 2020; 37(1):60-74. doi: 10.1016/j.rmr.2019.03.016

11. Wood LG. Asthma in the obese: A big and growing problem. American Journal of Respiratory and Critical Care Medicine. 2017; 195(1):4-5. doi: 10.1164/rccm.201608-1582ed

12. Yuan Y, Ran N, Xiong L, Wang G, Guan X, Wang Z, et al. Obesity-related asthma: Immune regulation and potential targeted therapies. Journal of Immunology Research. 2018; 2018:1-13. doi: 10.1155/2018/1943497
}

Стаття надійшла 30.07.2020 p. 